CZASOPISMO INŻYNIERII LĄDOWEJ, ŚRODOWISKA I ARCHITEKTURY JOURNAL OF CIVIL ENGINEERING, ENVIRONMENT AND ARCHITECTURE

JCEEA, t. XXXIII, z. 63 (3/16), lipiec-wrzesień 2016, s. 543-552

Wojciech ZALEWSKI ${ }^{1}$

\title{
OBLICZENIA CIEPLNE WYMIENNIKA STANOWIĄCEGO UJĘCIE DOLNEGO ŹRÓDŁA CIEPŁA POWIETRZNEJ POMPY CIEPŁA
}

\begin{abstract}
W pracy przedstawiono sposób przeprowadzania obliczeń cieplnych lamelowanego wymiennika ciepła, stanowiącego ujęcie dolnego źródła ciepła powietrznej pompy ciepła, pełniącego w obiegu termodynamicznym pompy funkcję parowacza. Podano algorytm obliczeń pozwalający na wyznaczenie pola powierzchni wymiany ciepła przy znanej wydajności cieplnej wymiennika. Posłużono się metodą NTU, służąca do przeprowadzania obliczeń cieplnych wymienników. Do wyznaczenia współczynnika przejmowania ciepła od strony powietrza zastosowano wzór Schmidta [4], dotyczący wymiany ciepła na powierzchniach ożebrowanych. Sprawność lameli określono w przybliżony sposób za pomocą wzorów odnoszących się do żeber, dzieląc lamelę na żebra o kształcie wynikającym z układu przestrzennego rur. W obliczeniach uwzględniono również, za pomocą współczynnika wymiany wilgoci $R C J$, wpływ ciepła utajonego wykraplającej się z powietrza pary wodnej na intensywność wymiany ciepła. Ze względu na możliwość pracy wymiennika w warunkach oszronienia powierzchni wymiany ciepła, przedstawiono sposób uwzględnienia wpływu powstającej warstwy szronu na wartość współczynnika przenikania ciepła. Współczynnik przejmowania ciepła przy wrzeniu czynnika roboczego w rurach proponuje się wyznaczać za pomocą uogólnionej korelacji Iwaszkiewicza [6]. Stosowanie wzorów Schmidta i Iwaszkiewicza ograniczone jest zakresami ich ważności, które podane są we wskazanych materiałach źródłowych. Przedstawiony algorytm obliczeń cieplnych wymienników lamelowanych może zostać wykorzystany do przeprowadzania obliczeń mających na celu weryfikację istniejących rozwiązań konstrukcyjnych, a także uzupełnienie i rozszerzenie danych eksploatacyjnych, podawanych przez producentów wymienników ciepła i pomp ciepła.
\end{abstract}

Słowa kluczowe: wymiana ciepła, lamelowany wymiennik ciepła, parowacz, współczynnik przejmowania ciepła, pole powierzchni wymiany ciepła

\section{Wprowadzenie}

Pompy ciepła zyskują ciągle na znaczeniu jako urządzenia grzewcze, stosowane głównie do ogrzewania pomieszczeń i przygotowania ciepłej wody użytkowej. W ostatnich latach daje się zauważyć gwałtowny wzrost popularno-

${ }^{1}$ Wojciech Zalewski, Politechnika Krakowska, Zakład Chłodnictwa i Klimatyzacji, al. Jana Pawła II 37, 31-864 Kraków; tel. 126283590; e-mail: wzalewski@pk.edu.pl 
ści pomp ciepła typu powietrze-woda, czyli takich, w których dolnym źródłem ciepła jest powietrze zewnętrzne lub powietrze wentylacyjne. Tylko w okresie od 2014 do 2015 roku nastąpił w Polsce ponad 70 procentowy wzrost liczby zamontowanych powietrznych pomp ciepła [1].

Wymiennikiem ciepła stanowiącym ujęcie dolnego źródła ciepła w tego typu pompach jest parowacz, czyli wymiennik, w którym zachodzi proces wrzenia czynnika roboczego. Najczęściej są to wymienniki z wymuszonym wentylatorem przepływem powietrza. Zasadniczą ich część stanowią wężownice wykonane $\mathrm{z}$ miedzianych rur i aluminiowych lamel.

Producenci pomp ciepła najczęściej oferują kompletne urządzenia, składające się ze sprężarki, wymienników dolnego i górnego źródła ciepła oraz potrzebnej automatyki. W niektórych przypadkach zdarzyć się może, że projektant zmuszony będzie do dobrania, a nawet zaprojektowania we własnym zakresie niektórych elementów pompy ciepła, w tym parowacza.

\section{Opis procesu odbioru ciepła w wymienniku}

Podczas pracy pompy ciepła w parowaczu następuje proces chłodzenia powietrza, przy czym może występować tylko sam odbiór ciepła z powietrza lub może mu towarzyszyć odprowadzenie wilgoci i osuszanie powietrza. Samo ochładzanie występuje wtedy, gdy temperatura powierzchni chłodzącej $T_{z}$ jest wyższa od temperatury nasycenia pary wodnej (temperatury punktu rosy powietrza $T_{R}$ ). Wtedy proces chłodzenia przebiega bez zmiany zawartości wilgoci w powietrzu.

Najczęściej temperatura powierzchni chłodzącej jest niższa od temperatury punktu rosy przepływającego powietrza. Wtedy wykrapla się na niej para wodna w postaci wody. Zachodzi więc jednocześnie proces ochładzania i osuszania powietrza. Przebieg zmian parametrów powietrza w wymienniku dla tego przypadku można przedstawić w sposób uproszczony na wykresie Molliera dla powietrza wilgotnego w układzie "entalpia właściwa $h$-zawartość wilgoci $x$ " w postaci odcinka "1-2" (rys. 1).

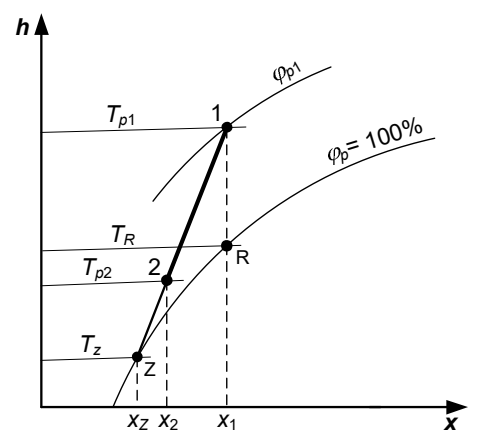

Rys. 1. Przebieg zmian parametrów powietrza w wymienniku: 1 - stan powietrza przed wymiennikiem, 2 - stan powietrza za wymiennikiem, $Z$ - stan powietrza nasyconego $\mathrm{w}$ średniej temperaturze powierzchni wymiany ciepła $T_{z}, T_{R}$ - temperatura punktu rosy

Fig. 1. Changes in air parameters inside the exchanger: 1 - air condition upstream of the exchanger, 2 - air condition downstream of the exchanger, $\mathrm{Z}$ - air in a saturated state at the mean temperature of the heat exchange surface $T_{z}, T_{R}$ - dew point temperature 


\section{Algorytm obliczeń cieplnych}

Przedstawiony zostanie sposób wyznaczania pola powierzchni wymiany ciepła wymiennika lamelowanego, stanowiącego ujęcie dolnego źródła ciepła (parowacza pompy ciepła), przewidzianego do pracy w określonych warunkach cieplno-przepływowych. Na podstawie otrzymanych wyników obliczeń możliwe jest dobranie lub zaprojektowanie wymiennika, który będzie w stanie odebrać odpowiednią ilość ciepła niskotemperaturowego, zapewniającego właściwe działanie pompy ciepła. Znając wymaganą wydajność pompy ciepła $\dot{Q}_{g}$ i określając parametry, realizowanego przez pompę, obiegu termodynamicznego, które determinują wartość współczynnika wydajności cieplnej pompy $C O P$, można wyznaczyć ze wzoru (1) wymaganą wydajność cieplną wymiennika dolnego źródła ciepła $\dot{Q}_{d}$ :

$$
\dot{Q}_{d}=\dot{Q}_{g} \frac{C O P-1}{C O P}
$$

Wartość współczynnika wydajności cieplnej COP zależy od rodzaju czynnika roboczego i parametrów pracy pompy (przyjętego obiegu termodynamicznego).

Jako dane do obliczeń przyjmuje się:

- parametry cieplno-przepływowe:

- wydajność cieplna: $\dot{Q}_{d},[\mathrm{~W}]$,

- strumień objętości powietrza: $\dot{V}_{p},\left[\mathrm{~m}^{3} / \mathrm{s}\right]$,

- temperatura i wilgotność względna powietrza na wlocie do wymiennika, odpowiednio: $T_{p 1},\left[{ }^{\circ} \mathrm{C}\right], \varphi_{p 1},[-]$,

- temperatura wrzenia czynnika: $T_{o},\left[{ }^{\circ} \mathrm{C}\right]$,

- praca w układzie ciśnieniowym (całkowite odparowanie czynnika w parowaczu).

- parametry konstrukcyjne:

- średnica zewnętrzna i wewnętrzna rur, odpowiednio: $d_{z}$ i $d_{w},[\mathrm{~m}]$,

- podziałka lamel: $t,[\mathrm{~m}]$,

- grubość lamel: $\delta_{z},[\mathrm{~m}]$,

- podziałka poprzeczna układu rur: $S_{q},[\mathrm{~m}]$,

- podziałka podłużna układu rur: $S_{l},[\mathrm{~m}]$.

Wydajność cieplną parowacza można wyznaczyć z zależności:

$$
\dot{Q}_{o}=\varepsilon \dot{W}_{p}\left(T_{p 1}-T_{o}\right)
$$

gdzie: $\varepsilon$ - sprawność termodynamiczna wymiennika,

$\dot{W}_{p}-$ pojemność cieplna strumienia powietrza, $[\mathrm{W} / \mathrm{K}]$ : 


$$
\dot{W}_{p}=\dot{V}_{p} \rho_{p} c_{p p} R C J
$$

gdzie: $\rho_{p} \quad-$ gęstość powietrza, $\left[\mathrm{kg} / \mathrm{m}^{3}\right]$,

$c_{p p}$ - ciepło właściwe powietrza, $[\mathrm{J} /(\mathrm{kg} / \mathrm{K})]$,

$R C J$-współczynnik wymiany wilgoci równy stosunkowi ciepła całkowitego do ciepła jawnego procesu; jeżeli w wymienniku zachodzi tylko proces chłodzenia powietrza, bez jego osuszania: $R C J=1,0$.

Wartość współczynnika $R C J$ można wyznaczyć z odpowiednich wzorów [2], [3] lub odczytać z wykresu Molliera.

Sprawność termodynamiczną parowacza $\varepsilon$ oblicza się z zależności:

$$
\varepsilon=1-e^{-N T U},
$$

a liczbę jednostek przepływu ciepła NTU:

$$
N T U=\frac{k_{A w} A_{w}}{\dot{W}_{p}}
$$

gdzie: $A_{w}-$ pole wewnętrznej powierzchni wymiany ciepła, $\left[\mathrm{m}^{2}\right]$,

$k_{A w}$ - współczynnik przenikania ciepła odniesiony do wewnętrznej powierzchni wymiany ciepła $A_{w},\left[\mathrm{~W} /\left(\mathrm{m}^{2} \mathrm{~K}\right)\right]$ :

$$
k_{A w}=\frac{1}{\frac{1}{\alpha_{o}}+\frac{\delta_{r}}{\lambda_{r}} \frac{d_{w}}{d_{m}}+R_{z}+\frac{A_{w}^{\prime}}{\alpha_{p}\left(A_{r}^{\prime}+\varepsilon_{\dot{z}} A_{\dot{z}}^{\prime}\right)}}
$$

gdzie: $\alpha_{o}$ - współczynnik przejmowania ciepła po stronie wrzącego czynnika roboczego w rurach, $\left[\mathrm{W} /\left(\mathrm{m}^{2} \mathrm{~K}\right)\right]$,

$\alpha_{p}$ - współczynnik przejmowania ciepła po stronie powietrza, [W/( $\left.\left.\mathrm{m}^{2} \mathrm{~K}\right)\right]$,

$\delta_{r}$ - grubość ścianki rury, [m],

$\lambda_{r}$ - współczynnik przewodzenia ciepła materiału rury, [W/(mK)],

$A_{r}^{\prime}$ - pole powierzchni zewnętrznej rury pomiędzy lamelami, $\left[\mathrm{m}^{2} / \mathrm{mb}\right]$,

$A_{\dot{z}}^{\prime}$ - pole powierzchni lamel, $\left[\mathrm{m}^{2} / \mathrm{mb}\right]$,

$d_{m}$ - średni promień rury, $[\mathrm{m}]$,

$\varepsilon_{\dot{z}}$ - sprawność lamel, [-],

$R_{z}$ - dodatkowy opór cieplny, np. zanieczyszczeń, [m² K/W].

Górny indeks „,” oznacza pole powierzchni odniesione do metra bieżącego długości rury. 
Współczynnik przejmowania ciepła od strony powietrza $\alpha_{p}$ wyznacza się za pomocą dowolnego wzoru odnoszącego się do opływu pęczka rur lamelowanych. Można posłużyć się na przykład wzorem Schmidta [4], który po przekształceniu i uwzględnieniu współczynnika $R C J$ przyjmuje postać:

$$
\alpha_{p}=K \operatorname{Re}_{p}^{0,6}\left(\frac{A_{c}^{\prime}}{A_{o}^{\prime}}\right)^{-0,15} \operatorname{Pr}_{p}^{1 / 3} \frac{\lambda_{p}}{d_{z}} R C J
$$

gdzie: $K$ - stała, zależna od układu przestrzennego rur; $K=0,22$ dla szeregowego układu rur oraz $K=0,38$ dla układu przestawnego,

$A^{\prime}{ }_{c}$ - pole zewnętrznej powierzchni wymiany ciepła (lamelowanej) równe sumie pola powierzchni rury pomiędzy lamelami $A_{r}{ }^{\prime}$ i powierzchni lamel $A_{\dot{z}}^{\prime}: A_{c}^{\prime}=A_{r}^{\prime}+A_{\dot{z}}^{\prime},\left[\mathrm{m}^{2} / \mathrm{mb}\right]$,

$A_{o}^{\prime}$ - pole zewnętrznej powierzchni rury gładkiej (bez lamel), $\left[\mathrm{m}^{2} / \mathrm{mb}\right]$,

$\operatorname{Pr}_{p}$ - liczba Prandtla,

$\lambda_{p}$ - współczynnik przewodzenia ciepła powietrza, [W/(mK)].

Liczba Reynoldsa powietrza $R e_{p}$ zdefiniowana jest wzorem:

$$
\operatorname{Re}_{p}=\frac{w_{o} d_{z} \rho_{p}}{\mu_{p}}
$$

gdzie: $\mu_{p}$ - współczynnik lepkości dynamicznej powietrza, [kg/(ms)], a $w_{o}$ oznacza prędkość przepływu powietrza w najmniejszym swobodnym przekroju wymiennika lamelowanego, określoną jak na rysunku 2 (wzory (9), (10)).
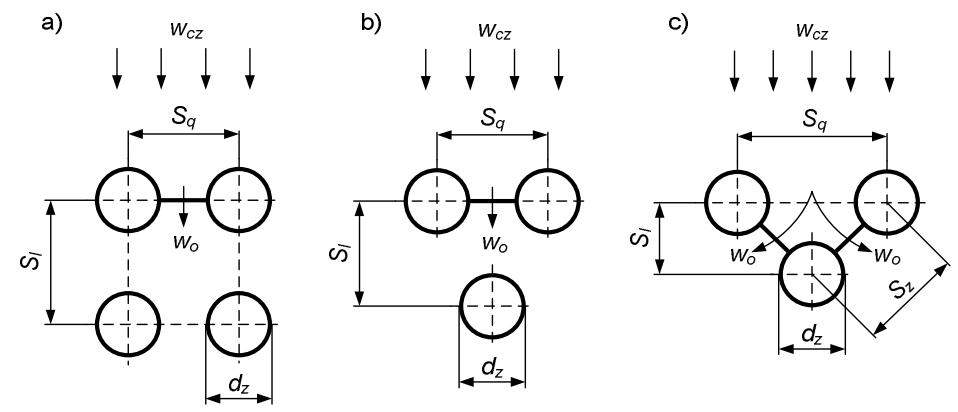

Rys. 2. Układ rur w wymienniku [3]: a) szeregowy; b) przestawny i $\left.\frac{S_{l}}{d_{z}} \geq 0,5\left(2 S_{q} / d_{z}+1\right)^{0,5} ; \mathrm{c}\right)$ przestawny i $\frac{S_{l}}{d_{z}}<0,5\left(2 S_{q} / d_{z}+1\right)^{0,5}$

Fig. 2. Exchanger tube bundle [3]: a) in-line; b) staggered and $\frac{S_{l}}{d_{z}} \geq 0,5\left(2 S_{q} / d_{z}+1\right)^{0,5} ;$ b) staggered and $\frac{S_{l}}{d_{z}}<0,5\left(2 S_{q} / d_{z}+1\right)^{0,5}$ 
Prędkość $w_{o}$ w przypadku powierzchni lamelowanych i szeregowego układ rur oblicza się z zależności:

$$
w_{o}=w_{c z} \frac{S_{q} t}{\left(S_{q}-d_{z}\right)\left(t-\delta_{\dot{z}}\right)}
$$

Dla przestawnego układu rur:

$$
w_{o}=\operatorname{MAX}\left(w_{c z} \frac{S_{q} t}{\left(S_{q}-d_{z}\right)\left(t-\delta_{\dot{z}}\right)} ; w_{c z} \frac{0,5 S_{q} t}{\left(S_{z}-d_{z}\right)\left(t-\delta_{\dot{z}}\right)}\right)
$$

gdzie podziałka diagonalna $S_{z}$ :

$$
S_{z}=\left(0,25 S_{q}^{2}+S_{l}^{2}\right)^{0,5}
$$

a $w_{c z}$ oznacza prędkość powietrza w obrysie czołowym wymiennika.

Sprawność lamel $\varepsilon_{z}$ wyznacza się w sposób przybliżony dzieląc lamele na żebra elementarne (rys. 3). Kształt tych żeber zależy od układu rozstawienia rur (szeregowy - prostokątne, przestawny - sześciokątne).
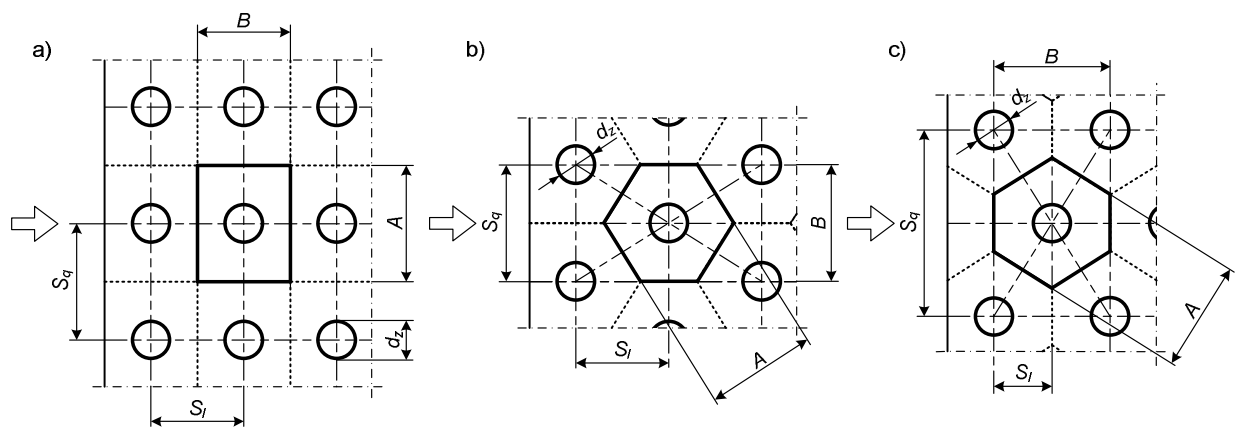

Rys. 3. Podział lameli na żebra [2]: a) szeregowy układ rur $\left(S_{q}>S_{l}\right)$; b) przestawny układ rur i $S_{l} \geq 0,5 S_{q} ;$ c) przestawny układ rur i $S_{l}<0,5 S_{q}$

Fig. 3. Division of plate fins into fins [2]: a) in-line tube bundle $\left(S_{q}>S_{l}\right)$; b) staggered tube bundle and $S_{l} \geq 0,5 S_{q} ;$ c) staggered tube bundle and $S_{l}<0,5 S_{q}$

$$
\varepsilon_{\dot{z}}=\frac{\tanh \left(m h_{\dot{z}}\right)}{m h_{\dot{z}}}
$$

gdzie:

$$
m=\sqrt{\frac{2 \alpha_{p}}{\delta_{\dot{z}} \lambda_{\dot{z}}}}
$$


gdzie: $\lambda_{\dot{z}}$ - współczynnik przewodzenia ciepła lamel, [W/(mK)].

Zastępcza wysokość żeber $h_{\dot{z}}$ [2], [3]:

$$
h_{\dot{z}}=\frac{d_{z}}{2}(\varphi-1)[1+0,35 \ln \varphi]
$$

gdzie:

$$
\varphi=\mathrm{Z}_{1} \frac{B}{d_{z}} \sqrt{\frac{A}{B}-Z_{2}}
$$

Wartości stałych $Z_{1}, Z_{2}$, oraz wielkości $A$ i $B$ zależą od kształtu żeber. Dla żeber prostokątnych: $Z_{1}=1,28, Z_{2}=0,2$ oraz $A=\operatorname{MAX}\left(S_{q}, S_{l}\right), B=\operatorname{MIN}\left(S_{q}, S_{l}\right)$. Dla żeber sześciokątnych: $Z_{1}=1,27, Z_{2}=0,3$ oraz $A=S_{z}, B=S_{q}$ gdy $S_{l}>0,5 S_{q}$ i $B=2 S_{l}$ gdy $S_{l}<0,5 S_{q}$ [2], [3].

Pompy ciepła pobierające ciepło z powietrza zewnętrznego mogą pracować także w niskich temperaturach, dochodzących nawet do $-20^{\circ} \mathrm{C}$. Wtedy ich efektywność działania radykalnie maleje i wymagane jest okresowe oszranianie powierzchni wymiany ciepła. Warstwa szronu tworzy się na powierzchni wymiany ciepła wtedy, gdy jej temperatura spada poniżej temperatury $0^{\circ} \mathrm{C}$. Chcąc określić wydajność wymiennika w tych warunkach należy zmodyfikować sposób wyznaczania współczynnika przejmowania ciepła $\alpha_{p}$. Obliczenia przeprowadza się dla pewnej przyjętej, uśrednionej grubości warstwy szronu $\delta_{s z r}$ (najczęściej przyjmuje się, że wynosi ona $15 \%$ odległości lamel), uwzględniając zmianę parametrów geometrycznych wymiennika.

W takim przypadku w obliczeniach należy uwzględnić zmianę, na skutek oszronienia, średnicy zewętrznej rury i grubości lameli oraz prędkości przepływu powietrza $w_{o}$, podstawiając we wzorach (7)-(10) w miejsce $d_{z}$ i $\delta_{\dot{z}}$ odpowiednio: $d_{z s z r}=d_{z}+2 \delta_{s z r}$ oraz $\delta_{z s z r}=\delta_{\dot{z}}+2 \delta_{s z r}$.

Wtedy współczynnik przejmowania ciepła po stronie powietrza $\alpha_{p}$, odniesiony do zewnętrznej, nieoszronionej powierzchni wymiany ciepła $A_{c}$ będzie wyrażał się zależnością:

$$
\alpha_{p}=\frac{1}{\frac{A_{c}^{\prime}}{A_{c s z r}^{\prime}} \frac{1}{\alpha_{p s z r}}+\frac{A_{c}^{\prime}}{A_{m s z r}^{\prime}} \frac{\delta_{s z r}}{\lambda_{s z r}}}
$$

gdzie: $\alpha_{p s z r}$ - współczynnik przejmowania ciepła do powierzchni oszronionej wymiennika, wyznaczony z uwzględnieniem zmiany geometrii wymiennika i prędkości przepływu powietrza $w_{o}$ spowodowanej oszronieniem, [W/( $\left.\left.\mathrm{m}^{2} \mathrm{~K}\right)\right]$,

$\lambda_{s z r}-$ współczynnik przewodzenia ciepła szronu, [W/(mK)],

$A_{c s z r}^{\prime}$ - pole powierzchni oszronionej wymiennika, $\left[\mathrm{m}^{2} / \mathrm{mb}\right]$,

$A_{m s z r}^{\prime}$ - średnie pole powierzchni oszronionej: $A_{m s z r}^{\prime}=0,5\left(A_{c}^{\prime}+A_{c s z r}^{\prime}\right)$. 
Stosowane w ogrzewnictwie pompy ciepła są najczęściej urządzeniami sprężarkowymi, pracującymi w układzie ciśnieniowym, tzn. z parowaczami zasilanymi w czynnik roboczy poprzez termostatyczny zawór rozprężny (zwykły lub elektroniczny). W celu obliczenia średniego współczynnika przejmowania ciepła po stronie czynnika roboczego należy zastosować wzór odnoszący się do przypadku wrzenia w warunkach konwekcji wymuszonej przy całkowitym odparowaniu czynnika. Proces przejmowania ciepła podczas wrzenia cieczy w przepływie jest procesem bardzo złożonym i trudnym do opisu matematycznego w sposób uogólniony. W celu wyznaczenia wartości współczynnika przejmowania ciepła można posłużyć się wzorem Mikielewicza [5], lub znacznie prostszym w stosowaniu, wzorem Iwaszkiewicza [6]. Poniżej przedstawiony zostanie sposób przeprowadzania obliczeń prowadzących do wyznaczenia współczynnika przejmowania ciepła $\alpha_{o}$ i pola powierzchni wymiany ciepła $A_{w}$ z wykorzystaniem wzoru Iwaszkiewicza, który można przekształcić do postaci:

$$
\alpha_{o}=C A_{w}^{-0,7}
$$

gdzie:

$$
C=2 \frac{\lambda^{\prime}}{l^{0,3}} A r^{-0,175}\left(\frac{P r^{\prime}}{K u}\right)^{0,35}\left(\frac{\dot{Q}_{d}}{r \mu^{\prime}}\right)^{0,7}\left(\frac{\rho^{\prime}}{\rho^{\prime \prime}}\right)^{0,525}
$$

oraz:

$$
\begin{aligned}
& A r=\frac{g l^{3}\left(\rho^{\prime}-\rho^{\prime \prime}\right) \rho^{\prime}}{\mu^{\prime 2}}-\text { liczba Archimedesa; } \quad \operatorname{Pr}^{\prime}=\frac{\mu^{\prime} c_{p}^{\prime}}{\lambda^{\prime}}-\text { liczba Prandtla; } \\
& K u=\frac{c_{p}^{\prime} \rho^{\prime} \sigma T_{o}}{r^{2} \rho^{\prime \prime 2} l}-\text { liczba Kutateładze, }
\end{aligned}
$$

gdzie: $\rho^{\prime}, \rho "-$ odpowiednio: gęstość cieczy i pary czynnika w stanie nasycenia, $\left[\mathrm{kg} / \mathrm{m}^{3}\right]$,

$\mu^{\prime}$ - współczynnik lepkości dynamicznej cieczy w stanie nasycenia, $[\mathrm{kg} /(\mathrm{ms})]$,

$\lambda^{\prime}$ - współczynnik przewodzenia ciepła cieczy w stanie nasycenia, $[\mathrm{W} /(\mathrm{mK})]$,

$\sigma$ - napięcie powierzchniowe, $[\mathrm{N} / \mathrm{m}]$,

$r$ - entalpia właściwa wrzenia, $[\mathrm{J} / \mathrm{kg}]$,

$c_{p}^{\prime}$ - ciepło właściwe cieczy w stanie nasycenia, $[\mathrm{J} /(\mathrm{kgK})]$,

$g$ - przyspieszenie ziemskie, $\left[\mathrm{m} / \mathrm{s}^{2}\right]$.

Charakterystyczny wymiar liniowy $l,[\mathrm{~m}]$ : 


$$
l=\sqrt{\frac{\sigma}{g\left(\rho^{\prime}-\rho^{\prime \prime}\right)}}
$$

Pole powierzchni wewnętrznej wymiennika $A_{w}$ można wyznaczyć z zależności:

$$
k_{A w} A_{w}=-\ln \left(1-\frac{\dot{Q}_{d}}{\dot{W}_{p}\left(T_{p 1}-T_{o}\right)}\right) \dot{W}_{p}
$$

wynikającej ze wzorów (2), (4) i (5).

Ponieważ współczynnik przenikania ciepła $k_{A w}$ jest funkcją pola powierzchni $A_{w}$ (wzory (6) i (17)), ostateczna postać funkcji, z której wyznacza się pole powierzchni wymiany ciepła $A_{w}$ jest następująca:

$$
f\left(A_{w}\right)=C_{1}+C_{2} A_{w}^{0,7}-A_{w}=0
$$

Stałe $C_{1}, C_{2}$ wynoszą:

$$
\begin{aligned}
C_{1} & =C_{3}\left(\frac{\delta_{r}}{\lambda_{r}} \frac{d_{w}}{d_{m}}+R_{z}+\frac{A_{w}^{\prime}}{\alpha_{p}\left(A_{r}^{\prime}+\varepsilon_{\dot{z}} A_{\dot{z}}^{\prime}\right)}\right) \\
C_{2} & =\frac{C_{3}}{C}
\end{aligned}
$$

gdzie:

$$
C_{3}=-\ln \left(1-\frac{\dot{Q}_{d}}{\dot{W}_{p}\left(T_{p 1}-T_{o}\right)}\right) \dot{W}_{p}
$$

\section{Wnioski}

Zaprezentowana metoda wyznaczania pola powierzchni wymiennika stanowiącego ujęcie dolnego źródła ciepła, pełniącego funkcję parowacza powietrznej pompy ciepła jest metodą prostą, a jednocześnie uwzględniającą wpływ wszystkich istotnych parametrów na działanie wymiennika.

Przedstawiony algorytm obliczeń cieplnych wymienników lamelowanych może stanowić cenną pomoc dla projektantów systemów grzewczych. Może zostać wykorzystany do przeprowadzania obliczeń mających na celu weryfikację istniejących rozwiązań konstrukcyjnych, a także uzupełnienie i rozszerzenie danych eksploatacyjnych, podawanych przez producentów wymienników ciepła i pomp ciepła. 


\title{
Literatura
}

[1] Spektakularny wzrost rynku powietrznych pomp ciepła w 2015 roku, Chłodnictwo, nr 3, 2016, s. 9-10.

[2] Niezgoda-Żelasko B., Zalewski W.: Chłodnicze i klimatyzacyjne wymienniki ciepłaobliczenia cieplne, Wydawnictwo Politechniki Krakowskiej, Kraków 2013.

[3] Zalewski W., Kot J.: Obliczenia cieplno-przepływowe wentylatorowych chłodnic powietrza, cz. I, Chłodnictwo, nr 1-2, 2015, s. 40-44.

[4] VDI-Wärmeatlas: Wärmeübergang an berippten Oberflächen, VDI Verlag, Düsseldorf 1991, S. Mb1-Mb4.

[5] Mikielewicz D., Mikielewicz J.: Analiza możliwości wykorzystania ogólnych korelacji wrzenia w przepływie w technice chłodniczej, Technika Chłodnicza i Klimatyzacyjna, nr 8, 1997.

[6] Madejski J.: Teoria wymiany ciepła, Wydawnictwo Politechniki Szczecińskiej, Szczecin 1998.

\section{HEAT CALCULATIONS FOR AN EXCHANGER CONSTITUTING THE INTAKE OF THE LOW TEMPERATURE HEAT SOURCE OF AN AIR-SOURCE HEAT PUMP}

\begin{abstract}
S u m m a r y
The paper presents the heat calculations for a plate finned heat exchanger constituting the intake of the low-temperature heat source of an air-source heat pump, operating as an evaporator in the pump's thermodynamic cycle. A calculation algorithm was provided to determine the heat exchange surface area for a given thermal efficiency of the exchanger. The $N T U$ method, used in heat calculations for heat exchangers, was applied. The air-side heat transfer coefficient was determined using Schmidt's equation [4] for heat transfer on finned surfaces. Plate fin efficiency was approximated using equations for fins - the plate fin was divided into fins whose shapes followed the spatial arrangement of the tubes. The $R C J$ damp transfer ratio was also used in the calculations to take account of the effect of the latent heat of the water vapour condensing out of the air on the intensity of the heat transfer process. As the exchanger is operational when the heat exchange surface is frosted over, the authors proposed a method to account for the effect of the frost layer on the value of the overall heat transfer coefficient. The heat transfer coefficient for the in-tube boiling process of the refrigerant was proposed to be determined using the generalised correlation by Iwaszkiewicz [6]. The application of the formulas proposed by Schmidt and Iwaszkiewicz is limited by their validity ranges, as stated in relevant reference works. The heat calculation algorithm for plate finned heat exchangers discussed in the paper may be used in calculations aimed to verify existing engineering solutions, as well as to supplement and expand on the operational data provided by heat exchanger and heat pump manufacturers.
\end{abstract}

Keywords: heat transfer, plate finned heat exchanger, evaporator, heat transfer coefficient, heat exchange surface area

DOI: $10.7862 / \mathrm{rb} .2016 .238$

Przestano do redakcji: $20.04 .2016 r$.

Przyjęto do druku: $30.11 .2016 \mathrm{r}$. 